Máté Szabó

\title{
From the Manorial Village to the Regional Center. The Economic Development of Barcs in the Period of Dualism
}

\begin{abstract}
At the very beginning of my essay I point out that what kind of natural and economical conditions Barcs have had in the 19th centuries. This is important becouse I had to place Barcs into this medium, which in the beginning of the 19th was a simple manorial village situated in the flood plain of the Drava. The Drava river had a great impact on the improvement of the village. This little manorial village by the end of the century became one of the determinative villages in the region of southern Transdanubia. I show why was the location of the village so importan at that time. As a vehicular interchange and with its warehouse capacity by the beginning of the 19th century it was significant too. There were five railway lines that are met in Barcs in the begining of the 20th century. So it was a significant vehicular intersection at that time. Furthermore after Kaposvár it was the second biggest industrial centre of the county. By this time it was famous about its wood and mill industries across Europe. Moreover it had a regional centre role at different types of food industries. I introduce to what kind of economical processies and infrastructural investments helped the large economical developement of the village. At the end of my essay I want to show the series of events which crash this tremendous economical and social change in Barcs after the World War I.
\end{abstract}

Keywords: manorial village, Drava river, industrial center, wood industry, infrastructure

\section{Introduction}

Until the bourgeois revolution of 1848 , the settlement of Barcs was part of the Csokonya estate owned by the Széchényi family. An important event in the history of the Széchényi family was the division of the property in 1814, after which the three sons of Ferenc Széchényi, Lajos, Pál and István, could take over their inheritance and start independent farming on the estates during its lifetime. The father took great care to ensure that his sons received exactly the same value from his possessions, and therefore he compiled it in the most detailed manner by the officials of his estates and assessed it on that basis for all his possessions. ${ }^{1}$ Until 1833, the manor belonged to István Széchényi, who then sold it to his brothers, Lajos and Pál. The Csokonya estate was a vast latifundium of about 62,000 Hungarian moons, with two market towns, several villages and a sheer. ${ }^{2}$ One of the market towns was the settlement of Barcs, which was an old crossing on the Drava to the Slavonian territories, the landlord operated a ferry, which was accompanied by the right to collect custom duties. In the middle of the 19th century, the village had about 5,000 Hungarian moons, and its population was approx. There were 1,700 people, basically Hungarian and German Catholics lived in the settlement. According to contemporary descriptions, quite a few watermills also operated on the Drava. With the parameters indicated above, Barcs exceeded the size of the usual settlements in Somogy county, but not much indicated the change that

\footnotetext{
1 Tilkovszky, Lóránt: Széchenyi István csokonyai uradalma. In: Somogy megye múltjából 1991. Edited by Kanyar, József. Kaposvár. 1991. 111.

2 Kaposi, Zoltán: A magyarországi uradalmi rendszer változásai a XVIII-XX. században. Agrártörténelmi Szemle. Historia Rerum Rusticarum. XLIII. (2001) 1-2. 239-261.; Kaposi, Zoltán: Uradalmak, földbirtokosok és birtokforgalom a Dél-Dunántúlon a 19. században. Mezőgazdaságtörténeti Tanulmányok 14. Budapest. MMGM. 2019.
} 
started in the middle of the 19th century. In our study, we follow how Barcs became the second largest settlement in Somogy county during the period of dualism, and what were the reasons for the incredibly rapid transformation process, which was rightly thought by contemporaries that there are hardly any similar examples abroad.

\section{Barcs in the middle of the 19th century: endowments, possibilities}

The current existence of the population of Barcs was significantly exposed to the natural conditions that give its surroundings. Of these, the Drava river was clearly the determining factor. In his work in 1812, György Károly Rumy mentions that the largest river in the county is the Drava, which originates in Tyrol and, passing through Carinthia and Styria, separates the three counties of Hungary, Zala, Somogy and Baranya, from Croatia and Slavonia. This river flows through sandy areas everywhere on the border of the county of Somogy, and thus rushes at a very high speed, surrounded by shores without strength. This is due in part to its winding flow, in part to the weakness and collapse of its shores, and finally to the flooding that has slowed and increased the flooding of adjacent lands as a result of the bends. ${ }^{3}$ The Drava changed its winding, branching bed quickly, and in addition to its main branches, it formed numerous smaller and larger branches, including islands of significant size. Such was the case between Croatia and Hungary, the long-disputed point of the Répás district. The Drava has a pretty big fall, moving rough gravel for a reefy, degenerate bed, with rapid changes, showing that it is doing filling work. The 10-15 km wide floodplain is full of dead beds and wet marshes, because the river fills its floodplain faster next to the riverbed than farther away. ${ }^{4}$ Along the Drava lay huge gallery forests that could provide the best quality timber, while also providing opportunities for diverse forest life for societies along the river.

Rumy's description is also confirmed by contemporary county maps. A few decades later, Elek Fényes characterized the Drava in such a way that the flow of "... is sweeping above it, causing a lot of damage with its floods. They wash gold from its grass, it has an abundance of fish, and its mills grind famous flour. Its shores are accompanied by famous beech and oak forests." ${ }^{5}$ The great acquaintance of the county, József Csorba, remarked in the middle of the 19th century that "there have been transport via the Drava from the memory of a person, and by boat and in a few places by bridge." ${ }^{\prime}$ In addition to the Drava, the Rinya is also fundamentally influences the operation of the settlement. Feeding on three branches, the Rinya flows into the Drava close to Barcs, forming the western border of the settlement. With its spring and autumn spills, it poses a serious threat to the agricultural production of the people of Barcs. The manorial regulation extended to this stream, and finally, in 1867, its head was to be submitted to the regulatory work. As the stream flowed into the Drava at the site of today's railway station, construction of the building was only possible after regulation. The area around the estuary and the stream bed was swampy, muddy. The stream was diverted to a new bed, the area was filled up. (The railway station was later built on this territory in 1868, and the central area of Barcs was also moved here. ${ }^{7}$ )

Since the end of the 18th century, the population of the Drava region has grown faster than the average. This is also clear in the case of Barcs. According to József II's census, only 355

3 The work of Rumy was translated and published by Tóth, Péter: Somogy megye leírása 1812-ből. In: Somogy megye múltjából 1988. Edited by Kanyar, József. Kaposvár, 1988.

4 Cholnoky, Jenó: Somogy megye természeti viszonyai. In: Magyarország vármegyéi és városai. Somogy. Edited by Csánki Dezső. Budapest, 1914.

5 Fényes, Elek: Magyarországnak, s a hozzá kapcsolt tartományoknak mostani állapotja statistikai és geographiai tekintetben 1. Pest. 1836.

6 Csorba, József: Somogy vármegye ismertetése. Pest. 1857. 58.

7 Harasztia, Attila: Barcs közlekedése a dualizmus korában, középpontban a vasúti közlekedés. Szombathely, 2005 . 
people lived in Barcs, while according to the data of 1828 , there were already 1,323 people living in the settlement, and in the middle of the century there were already 1,686 people living in the settlement. ${ }^{8}$ The increase can be attributed primarily to the fact that for a long time there was a lot of vacant land in this area and there was no enough free labour force to cultivate them, so it was worth deploying labor wherever it came from. This means that the settlements did not stop in the 18th century, even in the first half of the 19th century many newcomers arrived in Barcs or its surroundings. The family of Széchényi's had a big role in the settlements. This process was facilitated by the fact that in many parts of the Csokonya estate the soil conditions were very good for tobacco production. Not far from Barcs is the old center of tobacco production in Somogy county, the settlement of Szulok, which also belongs to the Csokonya estate. Tobacco production required primarily German speakers labours. Let's add that it was not happened only on the Széchényi's estates, but also in Németlad the Czindery family brought tobacco gardeners from Tolna county. ${ }^{9}$

There were other novelties in crop production in the first half of the 19th century. According to data of 1828, the previous two-pressure border use was replaced by three-pressure field production..$^{10}$ It was also a novelty that maize appeared in large-scale and residential production, which increased the possibility of animal feed, not to mention potatoes, which was so important in public nutrition and for which sowing data have also remained. Through the three-pressure system and the introduction of new plants, the production area has increased and productivity has improved. All these, of course, was the result of a long historical process: in agriculture, the new does not occur suddenly and does not crowd out the old at the same time. The robot was still used in the landlord's majors, traditional taxes remained important in the landlord's revenues, and so on. There is no doubt, however, that substantial changes always appear first in manorial farming.

The basis of animal husbandry was provided by the large forests and pastures of the border of Barcs. They could only use $1 / 3$ of the meadows belonging to the plot, the others gave more sedge than hay. ${ }^{11}$ And the common pasture was often flooded. Sometimes four times a year, as in 1825. ${ }^{12}$ This is why the forest pastures were in great need of both the landlord and the serfs. The Drava region has always been famous for its pig farming: in the first half of the 19th century, pigs were raised in huge herds to major national fairs, especially to the market of Kanizsa. ${ }^{13}$ The predominance of brittleness can be observed in cattle and pig farming, although we also know that Swiss type dairy farming was also practiced in several majors in the Csokonya estate of the Széchényi family. Stable animal husbandry will only become common in the last decades of the 19th century.

The market town of Barcs had the right to hold fairs. According to some data, the turnover and market suction power of its animal fairs were already so high in the early 19th century that the fair of the manorial center was almost depopulated. The infrastructural conditions which determining the life of the settlement were acceptable. The southern post route ran along the Drava, meaning that the accessibility of Barcs and then the possibility of crossing the Drava was a huge potential. The postal route led to Nagykanizsa from the edge of Baranya county through

8 Danyi, Dezső - Dávid, Zoltán: Az első magyarországi népszámlálás (1784-1787). Budapest. 1960.; Nagy, Ludovicus: Notitae Politico - Geographico - Statisticae Inclyti Regni Hangariae, Partiumque Eidem Adnexarum. Buda, 1828. Volume 1.; Fényes, Elek: Magyarország geographiai szótára 1-2. Pest. 1851.

9 Kaposi, Zoltán: Uradalmak, földbirtokosok... 62.

10 Magyar Nemzeti Levéltár Somogy Megyei Levéltára (hereinafter: MNL SML). IV. 1. h. Conscr. Regnicolaris, 1828.; T. Mérey, Klára: A földmúvelési rendszer alakulása Somogy megyében 1720-1848. Agrártörténeti Szemle IV.1-2. 1962.

11 MNL SML IV. 1. h. Conscr. Regnicolaris, 1828. Barcs.

12 Magyar Nemzeti Levéltár Országos Levéltára (hereinafter: MNL OL): P 623. IV. 03.08.1825.

13 Kaposi, Zoltán: Kanizsa gazdasági struktúrájának változásai 1743-1848. Nagykanizsa. 2009. Czupi Kiadó. 224225. 
Szigetvár, Istvándi, Komlósd, Babócsa, Berzence and Iharosberény in Somogy county. ${ }^{14}$ These settlements could be attributed in part to their economic development by being able to take advantage of the postal and trade route. Let us add that in the middle of the century Szigetvan was one of the most developed settlements in this region and in the county, where six fairs were held every year, and weekly fairs on Tuesdays and Fridays. Szigetvár's role as a market center was indisputable, it could not only take advantage of the benefits of through trade, but it also attracted the surrounding settlements. ${ }^{15}$ The possibility is important even if we know that the quality of the county road network during this period was rather poor. The manual and cart labor required for road construction and repair was provided by the localities according to their population. The obligation to repair applied only to state and law enforcement roads that were marked as postal or highway. To this day, you can walk almost the entire length of the old postal road.

\section{Population and society in the second half of the 19th century}

As a result of the laws of 1848 , the relationship between the manor and the market town changed fundamentally during the years of absolutism. The economic situation of the Széchényi estate changed in accordance with the new laws. The production costs of the majors increased because he lost the robot, the ninth, and the lord even had to pay taxes. His situation was further hardened by the state tobacco monopoly which was enacted in 1851. As a result, the income of the manor declined. The managers of the dominion have clearly seen that they do not have enough wages and technical equipment, so they must strive to make more optimal use of the land. In addition, the question of the ownership of former common use lands had to be resolved. Both the large landowner and the population were interested in carving out as much of the forests and pastures as possible.

In the second half of the 19 th century, the population of historic Hungary grew rapidly. This is also clear in the case of the population of Barcs. According to the census of 1857 Barcs had 1,708 inhabitants. ${ }^{16}$

Figure 1. The population of Barcs between 1869 and 1910

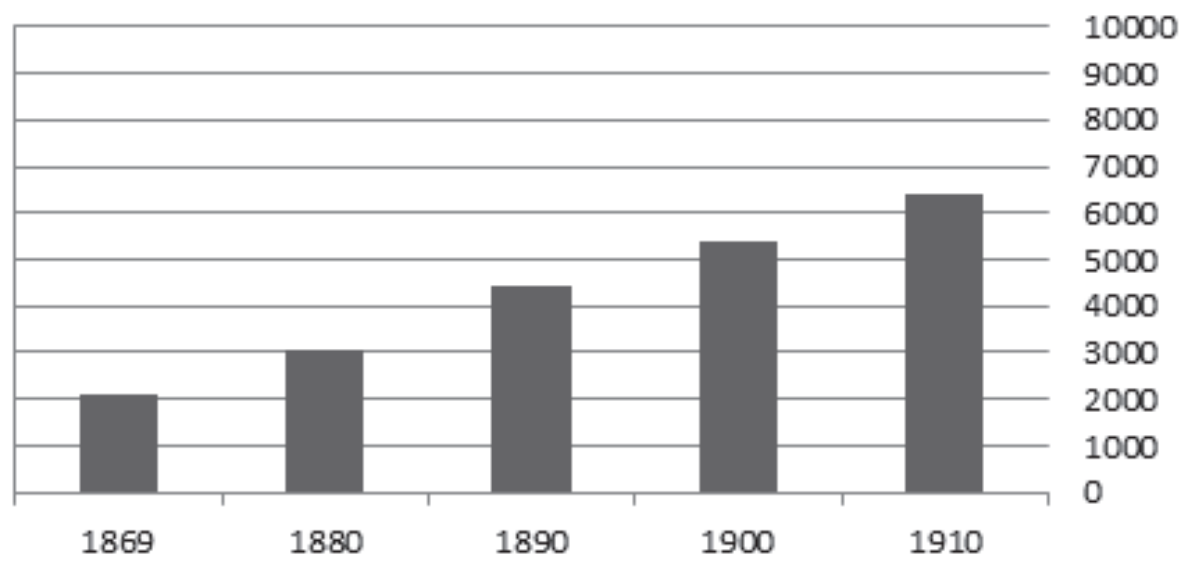

Source: A Magyar Korona országaiban az 1870.év elején végrehajtott népszámlálás eredményei a hasznos háziállatok kimutatásával együtt. Pest, 1871.; A Magyar Korona országaiban az 1881. év végén végrehajtott népszámlálás

14 Erdósi, Ferenc: Somogy megye közlekedési hálózatának kialakulása a XIX-XX. században. A vasúthálózat kialakulása. In: Somogy megye múltjából 1982. Edited by Kanyar, József. Kaposvár, 1982.; Tóth, Péter: Somogy megye leírása 1812-ből...

15 Szili, Ferenc: Somogy megye kereskedelme a kései feudalizmus korában (1700-1848). Kaposvár. 1988.; Kaposi, Zoltán: A nagybirtok modernizációjának lehetőségei a 19. századi Dél-Dunántúlon. In: A tudomány és az oktatás vonzásában. Edited by Kaposi, Zoltán - Lendvai, Tamás - Oroszi, Sándor. Pécs, 2012. 59.

16 A Magyar Korona országaiban az 1870. év elején végrehajtott népszámlálás eredményei a hasznos háziállatok kimutatásával együtt. Pest, 1871. 584. 
főbb eredményei megyék és községek szerint rendezve II. Budapest, 1882.; A Magyar Korona országaiban az 1891. év elején végrehajtott népszámlálás eredményei. I. Budapest, 1893.; A Magyar Korona országainak 1900. évi népszámlálása 1. Budapest, 1902.; A Magyar Korona országainak 1910. évi népszámlálás 1. Budapest, 1912.

It can be seen that the growth was very significant, far exceeding the indicators typical of the county or the whole country. By 1870, there were already 2,111 inhabitants registered. At the time of the 1880 census, it had grown to 3,080, in 1890 to 4,427, in 1900 to 5,388, while the last pre-war 1910 census showed 6,415 inhabitants. In total, between 1857 and 1910, the population of the settlement increased by 4,707 people. It is clear that in such a short period of time, growth of this magnitude can only be achieved with a significant number of settlers, and natural growth would have resulted in only one-third of this increase. Of course, the population also includes the datas of the outskirts of the settlement. In the 1910 statistics, two inhabited steppes are mentioned: 185 persons lived in Nagyerdő-puszta, while in Sáncz-puszta there were only 171. The population growth in Barcs far exceeded the increase in the market towns of the region. This is well illustrated by the fact that according to the 1910 census, there were 4,593 people in Csurgó, 4,558 in Marcali, 3,753 in Nagyatád and 6,153 in Szigetvár.

Figure 2. The population of Somogy county between 1869 and 1910

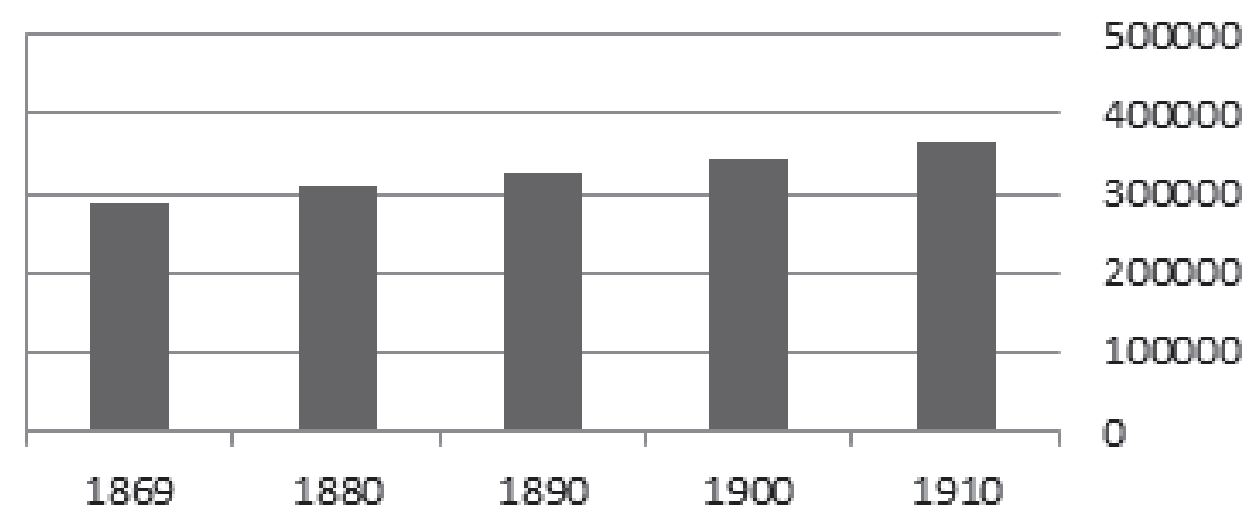

Source: A Magyar Korona országaiban az 1870. év elején...; A Magyar Korona országaiban az 1881. év végén...; A Magyar Korona országaiban az 1891. év elején...; A Magyar Korona országainak 1900. évi népszámlálása...; A Magyar Korona országainak 1910. évi népszámlálás...

It is worth looking at the population change of Barcs from another point of view. If we examine the changes in the population of Somogy county, we can see that between 1869 and 1910 there was a much smaller increase in the county. The population of Somogy county was 287,555 in 1869 and 364,799 in 1910 , so the population of the county increased by 77,240. In the case of Barcs, the annual growth rate is $2.75 \%$, while in the county it is only $0.58 \%$.

Let's see what the occupational structure of the settlement was like, and whether something special can be seen in the social system of Barcs. In 1876, the Sopron Chamber of Commerce and Industry counted those who were involved in industry and commerce in all settlements of the nine counties under its supervision. In Barcs, 68 self-employed industrial and commercial entrepreneurs, 61 assistants, 37 apprentices and 29 male workers were registered this year. If we consider 1,000 of the 2,111 inhabitants to be earners, the proportion of the working population engaged in industry and trade (197 people) is still close to $20 \%$ of all earners. There were 426 agricultural day laborers. This shows that Barcs was no longer a traditional agricultural settlement just a few years after the lawsuit closing the landlords. ${ }^{17}$

17 T. Mérey, Klára: Barcs gazdaság- és társadalomtörténete a kapitalizmus korában. In: Barcs múltja és jelene. Edited by Bihari Ottó. Barcs, 1979. 42. 
It is clear from the data that at the beginning of the age of dualism, significant industrial and commercial development may have begun in Barcs. If we examine the occupational composition of the population of Barcs around the turn of the century, we get a completely different situation from the county.

Table 1. The employment structure of Barcs in 1900 and 1910 (earners)

\begin{tabular}{|c|c|c|c|c|c|c|c|}
\hline Year & \multicolumn{2}{|c|}{ Population } & Agriculture & Industry & $\begin{array}{c}\text { Commerce } \\
\text { and Finance }\end{array}$ & Transportation & $\begin{array}{c}\text { Public } \\
\text { servants }\end{array}$ \\
\hline & Earners & Dependants & & & & & \\
\hline 1900 & 2286 & 3110 & 647 & 619 & 224 & 303 & 117 \\
\hline 1910 & 2663 & 3752 & 612 & 706 & 363 & 363 & 122 \\
\hline
\end{tabular}

Source: A Magyar Korona országainak 1900. évi népszámlálása...; A Magyar Korona országainak 1910. évi népszámlálása...

It can be seen from the data that although agriculture is still an important economic sector of the settlement, the dynamics is provided by other sectors. The number of workers in industry, commerce and credit grew steadily until the outbreak of World War I. The increase in employment in the transport sector is due to, among other things, there were significant investments in infrastructure during this period. The public service system has so far been fully developed, with a long line of institutions, so there has been no significant increase here. At that time, the number of enterprises engaged in industry increased from 214 to 247, most of which were unassisted enterprises, so they were sole proprietorships. In the censuses, the data of large companies employing more than 20 workers per settlement have already been recorded. In 1900, there were 3 such larger companies in Barcs. The concentration of Barcs industry is shown by the fact that $11.5 \%$ of the workers working in large companies in the whole county were employees of the three large factories in Barcs at that time. ${ }^{18}$ In the early 1900s, Barcs had a significant number of commercial companies, financial institutions, post and telegraph offices, railway stations, shipping companies and other industrial plants. In other words, it is quite clear from the employment statistics that Barcs has become a dominant industrial and commercial settlement in the region with significant capacities.

\section{Agricultural conditions in Barcs in the second half of the 19th century}

From the 1850s to the mid-1880s, there was an agricultural boom in Hungary, when everyone tried to take advantage of the expanding market and rising prices. ${ }^{19}$ This, of course, required stable land ownership. The first step in this was created by law in 1848, but procedures for common lands were at least as important. In Barcs this process took quite a long time, and finally it was not completed until 1864. From then on, peasant farming took place on an estate separate from the landlords. ${ }^{20}$

Until 1848, the manor of Csokonya was kept under its own management by the owners, where they practiced manorial farming. After 1848, a significant part of the lands were still in the hands of the Széchényi family. After the death of Count Lajos Széchényi, Count Imre from his second wife inherited Barcs, and Count Dénes Széchényi took over from him. But the lord's possession was not motionless either. We need to mention two important processes in this matter. One is that smaller or larger estates were sold in the second half of the 19th century

18 A Magyar Korona országainak...1902.975. At that time, a total of 860 workers worked in 13 large companies in Somogy county, including the Kaposvár sugar factory.

19 Kaposi, Zoltán: A kiegyezés szerepe a magyarországi mezőgazdaság fejlődésében. Agrártörténeti Szemle, LVIII. 2017.1-4. 67-88.

20 T. Mérey, Klára: Barcs gazdaság- és társadalomtörténete...39. 
from the area of the former Csokonya estate. These estates were not too large. Our other remark is that in the age of dualism, a significant part of the land was leased, but not all at once, as a large lease, but rather per village, so that the landlord's estates there could be priced differently. The proliferation of large leases is a rather general trend in the country in the past, not only in Somogy county. ${ }^{21}$

In 1895, Barcs had a large estate in the hands of two owners: Jr. Count Imre Széchényi and Zsófia Stern owned larger lands. The two of them own 3,631 cadastral moon. Zsófia Stern's father was a merchant from Nagykanizsa. The land of Jr. Count Imre Széchényi in Barcs was rented entirely by the merchant Adolf Fuchs. The appearance of a family from Nagykanizsa is not surprising, as it is known from the literature that in the age of dualism, dozens of entrepreneurs from Kanizsa, most of them traders, bought larger estates in Southern Transdanubia. ${ }^{22}$

If we look not only at the large estates, but at the whole agriculture of Barcs, we see that in 1895 there were 409 agricultural farms in Barcs, covering 4,323 cadastral moon. The 409 farms have 692 cadastral moon shared to varying degrees. It can be seen that the previous situation has not changed much: the vast majority of the lands were large estates. ${ }^{23}$ And if we contrast this data with the data of the census survey conducted 5 years later, which in Barcs had 163 smallholders, 16 smallholder day labourers, 233 agricultural workers and 171 economic servants with 362 dependents. The number of people living from agriculture was about 700 , the $13 \%$ of the population. ${ }^{24}$ It can be stated that the results of agriculture mainly reflect the results of the manor.

We also have information about the extent of tobacco production, which largely determines the arable farming. The salt house, built by Ferenc Széchényi, was converted into a tobacco substitute in 1851, as the supply of salt to the Drava ceased. In 1882, 149 tobacco growers in Barcs produced $88,269 \mathrm{~kg}$ of tobacco leaves on $250 \frac{1}{2}$ acres of land. ${ }^{25}$ The amount of tobacco area thus decreased compared to the 1850 s, when it was grown on 937 acres. ${ }^{26}$ Barcs was still in second place in the county, in terms of the number of growers and the size of the tobacco field, after Mike.

In $1865,40 \%$ of the border of Barcs was covered with forest. In 1895, 30 years later, the proportion of forest fell to 20\%. In Barcs, significant deforestation took place in the areas along the Drava, due to which the proportion of arable land increased. In Somogy county, the proportion of forests decreased from only $30 \%$ to $21 \%$ during the same period. Arable farming in particular has strengthened. In addition, infertile areas were cleared at a high pace: including reeds, the unused area on the outskirts of the settlement decreased by nearly 222 acres between 1865 and 1895. In the middle of the 1890s, some pastures of the village of Barcs were divided, during which the people of Barcs had to agree with the Kremzir family, who owned the border, in addition to the Somogytarnóca estate. At that time, a change of ownership was even carried out with the Széchényi estate. As a large part of its land was owned by large landowners, a significant part of the livestock was also carried out by them.

In 1884 a new farm appeared in Barcs. In December of this year, the Barcs Pig Fattening Limited Liability Company, whose headquarters were located in Barcs, was registered with the court of registration. The company dealt with commission fattening of pigs and their sale and

\footnotetext{
21 A Magyar Korona országainak mezőgazdasági statisztikája 2. Budapest, 1897. 100.

22 Kaposi, Zoltán: Nagykanizsai vállalkozók birtokszerzései a város körüli területeken a dualizmus korában. In: Magyar Gazdaságtörténeti Évkönyv 3. Uradalom - Vállalat. Edited by Kövér, György. 2019. 223-241.

23 T. Mérey, Klára: Barcs gazdaság- és társadalomtörténete...46-47.

24 A Magyar Korona országainak 1900. évi népszámlálása...215-216.

25 A Pécsi Kereskedelmi és Iparkamara jelentései. Pécs. 1882. 25.

26 MNL SML. Documents of the County Headquarters, Statement of the tobacco production according to the number of moons in 1850 and 1851 and the difference between the cultivation between the two years.
} 
purchase. ${ }^{27}$ Furthermore, as early as 1909 , it supplied electricity to Barcs from its own power plant. The Széchényi family was also interested in this company.

In the second half of the 19th century, the renewal of technical equipment and the reorganization of the technological system played an increasingly important role in large-scale farming. More and more modern machine devices appeared in the Széchényi estate as well. The manor kit already included a steam engine, threshing machine, seed drill, iron harrow, or forage harvester, iron harrow, iron cylinder, etc. in the economic toolbox.

\section{Major industrial enterprises in the settlement between 1867 and 1914}

All forms of industry were present in Barcs. Traditional meant small-scale industry: smallscale, mainly family-run industrial production has always been strong. In Hungary, the guild system was severely weakened by the industrial order established following the imperial patent of $1859 .{ }^{28}$ Our industrialists could no longer adapt to the expansion of consumption, the transformation of its structure and quality requirements, and the competition of cheap mass products within the framework of guilds. The former guilds were unable to accept new, state-ofthe-art manufacturing processes due to their closed nature, and the number of professionals was reduced due to the recruitment of fewer and fewer butlers. The role of the guilds was taken over in most places by the industrial associations, the industrial association was established in Barcs in 1874, which became a new organization of the masters, more open than the guild. ${ }^{29}$ In reality, however, guild traditions and customs continued to live on for a long time, until the middle of the 20th century. The older masters still raised their disciples in the spirit of these.

The future, of course, was the manufacturing industry. An important sector of the industrial development of Barcs was the wood industry by taking advantage of the natural endowments. In 1882, according to the report of the Pécs Chamber of Industry, there were two wood sawmills in Barcs, one for Schmidt et al and the other for Jenő Schmidt. Both carried out the classification of the delivered trees and their preparation as semi-finished products. The wood, after being dried in a drying chamber, was transported to France. In addition, cooper wood was sold in Barcs, although much of it was obtained from Slavonia and sold. ${ }^{30}$ The importance of the wood industry is shown by the fact that several companies registered with foreign capital also worked in Barcs. For example, on December 24, 1884, the company Sociéte d Importation de Chéne, headquartered in Paris, established a branch in Barcs and registered it with the Kaposvár court of registration. The company's main goal was to transport, buy, sell and process oak trees in the raw state. ${ }^{31}$ Furthermore, an oak bark tanning company was established in the settlement in 1889. ${ }^{32}$ In 1893, in the report of the Pécs Chamber of Commerce and Industry also published data about other large companies, such as the wood industry plant of Count Széchényi Géza and the steam sawmill of Faipartelep Rt. ${ }^{33}$

The food industry in Barcs was equally important. In 1889, the distillery and refinery of Mór Kremzir, a resident of Barcstelep, were registered in the court of registration. ${ }^{34}$ The entrepreneur has become one of the most significant businessmen of Barcs over time. His father, Károly Kremzir, was born in 1818 and settled in Barcs and Pálfalu in the early 1840s. (Later

MNL SML. VII. 1. f. Cégbírósági iratok 1875-1950. Company court documents. I. 94/I.

Kaposi, Zoltán: Magyarország gazdaságtörténete 1700-2000. Budapest-Pécs. 2002. 240-241.

29 Rózsás, Márton: Az idő sodrában - Barcs története dióhéjban, Dráva menti füzetek 5. Barcs. 2005. 46.

30 MNL SML.VII.1.f. Cégbírósági iratok 1875-1950. Company court documents. I. 75/1.; A Pécsi Kereskedelmi és Iparkamara jelentése. Pécs. 1882. 67.

31 MNL SML. VII. 1. f. Cégbírósági iratok 1875-1950. Company court documents. 92/I.

32 A Pécsi Kereskedelmi és Iparkamara jelentése. Pécs. 1890.18.

33 A Pécsi Kereskedelmi és Iparkamara jelentése. Pécs. 1894. 88.

34 MNL SML. VII. 1. f. Cégbírósági iratok 1875-1950. Company court documents. Sole proprietorships. II. 155. 
Drávapálfalu, today Barcs) He visited the area collecting iron, glass and bone waste and skins. In 1848, he rented the Belcsa-puszta estate on the eastern border of Barcs, which he bought in 1866, from the money he had collected as a result of his hard and persistent work. He died in 1888. His son, Mór Kremzir, was born in 1866 in Barcs. After his father's death, he took control of the estate. He later managed it with his two sons. He created a model farm in a few years that was unprecedented in the area. ${ }^{35}$ According to rumors, the Széchényi family advised the sale of their property to their administrator, as he believed that the arable land on this estate was of very poor quality and would make a good deal if it was sold. After the Széchényi found out that Kremzir had set up a model farm in a few years, they immediately knocked out their manager.

Mór Kremzir set up a distillery in Belcsapuszta, belonging to Pálfalu, with large-scale constructions and investments, with such production that he paid a tax of 180,000 forints a year for the distillation itself. In 1893, the largest distillery in the Pécs Chamber of Commerce and Industry was owned by Mór Kremzir, and he submitted the official report to the Chamber on the annual situation of the distillery industry. The decline in spirits exports and the increase in production costs have forced the distillery to operate throughout the year as well. The raw material for this was provided by three agricultural distilleries established in its neighborhood. Its factory refines $9,000 \mathrm{hl}$ of alcohol per year. The operation of the factory was adversely affected by the fact that although it was close to the Pécs coalfield, the private railway transported coal for almost twice the price of the state railway. ${ }^{36}$ The Kremzir family helped Barcs develop in addition to successful farming. He was a constant supporter of the Fire Brigade Association, the Theater, the Sport Club, the Casino and various amateur groups.

A steam mill was also established in Barcs. Creating a joint stock company to create a steam mill was not an easy task. Count Imre Széchényi and Géza convened a meeting twice to subscribe for the shares of the mill, which was eventually established with the share capital of 1,400,000 crowns under the name of Barcstelepi Mümalom Rt. ${ }^{37}$ In addition, Sertéshizlaló Rt. also had its own steam mill. One of the last large enterprises was the construction of the Union mill in 1912. This huge mill complex was considered to be the second largest in Hungary, but also the largest and most modern in Central Europe. It also met domestic and export needs when it was working at full capacity. It burned twice in ten years, in 1914 and 1916, so it produced predominantly only "semi-steam".

In the industry of stone, sand and clay we could also find a factory: the brick factory of Barcsi Körkemence Rt., Which was founded in $1893 .{ }^{38}$ This venture was apparently brought to life by the general boom of Barcs.

\section{Transport and trade changes}

The railway played a significant role in the development of Barcs. The Murakeresztúr-Barcs section was started by the Southern Railway, while the Pécs-Barcs section was managed by the Pécs-Barcs Railway Company. Between the two main lines, the Pécs-Barcs railway was completed first, it was handed over on May 6, 1868, and the Barcs-Murakeresztúr line operated from September 1, 1868. The residents of Barcs welcomed the incoming development, and both the local and national press covered the events on the front page. The enthusiasm of the people of Barcs was not typical of the inhabitants of Somogy county. The line bypassed the central parts of the county, including Kaposvár. The county's second railway line (the first on the southern shore of Lake Balaton) was not expected to have a positive impact on the county's

35 http://www.somogyitemetkezes. hulelodeink/nev-szerinti-lista/145

36 T. Mérey, Klára: Barcs gazdaság- és társadalomtörténete...45.

37 Somogy, 06.11.1893. - Somogy, 07.02.1893.

38 A Pécsi Kereskedelmi és Iparkamara jelentése. Pécs, 1894. 110-111. 
economy. The public opinion of the county was afraid of the inflow of cheap grain from Bačka and the Great Plain, they were afraid of its market-influencing, price-reducing power. However, the rapid increase in traffic at the port and train station and the development of the city's economy proved the rightness of building the railway lines.

The development of local railways was greatly facilitated by the laws that applied to them in the 1880s. The main purpose of these was to encourage an increase in the weight of private investment in railways over public investment. The first HÉV that affected Barcs was the BarcsPakrác HÉV, which opened in $1885 .{ }^{39}$ The Hungarian section was very short, leading from the railway bridge built on the Drava to the railway station. The purpose of the line was to connect the areas of Croatia with Barcs. This was preceded by the transport of timber from Slavonian oaks to Barcs. The wood delivered to Barcs was processed and transported to the western markets as a semi-finished or finished product. Prior to the construction of the railway bridge and railway line, this large amount of timber was solved by floating or transporting by ship. Then in 1883 a wooden bridge over the Drava was built. From then until the construction of the railway bridge, the timber was mainly transported to Barcs by carts.

Two bridges crossed the Drava near Barcs during this period. The substructure of both bridges was stone and the superstructure was an iron structure. The length of the road bridge was $319.8 \mathrm{~m}$ and of the railway was $271 \mathrm{~m}$. Within the framework of the national bridge construction program, between 1902 and 1903, a new $280 \mathrm{~m}$ long road bridge was built with stone pillars sunk $20 \mathrm{~m}$ deep into the riverbed in the line of the demolished wooden bridge. Traffic was maintained by ferry during the construction. The bridge was ceremoniously handed over to the traffic on November 3, 1903. ${ }^{40}$

The next HÉV was the line between Barcs and Somogyszob, which was handed over in 1890. One of the main goals of its construction was, among other things, to get the Széchényi (Géza and Imre) manors of Csokonya, Tarnóca, and Barcs to the railway, thus opening the more distant markets to their crops. The largest owner of the joint-stock company that built and operated the line was the Széchényi family. This line helped to ensure that the tobacco which was produced in the Csokonya-based estates of the Széchényi family could be transported via Barcs to the Tobacco Factory in Pécs, which was their largest market. Probably this is why the line was called the „Tobaccorailway” by the people of Barcs. ${ }^{41}$ Additional railway lines of local interest were built. The HÉV line between Kaposvár and Barcs was completed in 1905, which, contrary to the original plans, joined the Pécs-Barcs railway not at Drávapálfalu but at Középrigóc. The next and last built HÉV was the Barcs - Sellye - Siklós line, which was opened in 1912.

From the middle of the 19th century onwards, the creation of the technical preconditions for steamship and the need for transport sufficient to start economical traffic had been given. Still, the transporting by steamboats could only start slowly on the river. The main reason for this was the deregulation of the Drava. The river also changed direction frequently and unexpectedly because of the stumps in its bed. Behind them, alluvium accumulated, creating reef islands that again only changed the direction of the river. Logs are released into the water from the washedup shores frequently. ${ }^{42}$ These problems were overcome by significant regulatory work in the 1880s. After Bernhard Richard's steamship operation in 1817, which lasted about four years, a steamship appeared in Barcs in 1856, but it was already owned by the Danube Steamship Company (hereinafter DGT). As early as the 1860s, a regular combined passenger-cargo flight

39 Kaposi, Zoltán: Evangélikus földesurak gazdasági és társadalmi jelentősége Dél-Dunántúlon a 19. században. In: A reformáció a Dél-Dunántúlon. Edited by Borsy Judit. Pécs - Kaposvár - Szekszárd, 2019. 266.

40 Barcs és Vidéke, 03. 11. 1903.

41 Harasztia, Attila: Barcs közlekedése...50.

42 Vizügyi és Hajózási Közlöny, 1907. No. 41.322. 
was launched. Until 1865, DGT steamers sailed from Osijek to Kakonya. It was a $229 \mathrm{~km}$ stretch. Its flights on this route were discontinued by the company in 1865, claiming that this long flight was unprofitable for it. Thereafter, DGT carried out only occasional transport between Osijek and Barcs and was only willing to transport in larger batches. ${ }^{43}$

Thanks to water regulation work in the 1880 s, the river became even more navigable. From that time until World War I, was the heyday of the shipping on Drava, and it developed rapidly again. The reason for the increase in traffic was the rapid development of trade in Barcs, which was located at the meeting point of the Southern Railway and the Pécs-Barcs Railway in the 1880s. The raw material was demanded by the masses of large factories and commercial companies established in Barcs. There was a great demand for Slavonian wood. Transport to the ship was the most suitable to meet this demand until the bridges were built. The main transport profile, on the other hand, was grain. In addition to the natural conditions, the transport volumes were also affected by the yields of the grain-exporting areas of South-Eastern Europe. During this period, the steamers sailed mainly to Barcs on the Drava. The reason for this was the development of Barcs in other transport sectors (railways) and the development of the appropriate quality reception and transhipment infrastructure. In fact, a commercial port was built on the Drava in two places, Osijek and Barcs. In Osijek there was a harbor basin, in Barcs a $2.2 \mathrm{~km}$ long quay for ships, with warehouses and railway connecting tracks.

Even then, sailing on the river still posed dangers. Some examples of this statement. In 1902, a cargo ship sank from Kaproncza to Barcs in a vortex at the pillar of the road bridge of Barcs. ${ }^{44}$ Or, for example, in April 1909, the raft from Mária-Rast to Barcs disintegrated with five wagons of building timber and planks near Bélavár. ${ }^{45}$

Between the two shipping directions, the traffic from the Danube estuary was clearly higher, exceeding the volume of transport from Barcs by six to seven times in some years. In the upper part of the Drava (up from Barcs) there was only a downward voyage. The transport of lowland wheat to the Alps and the Adriatic provinces and countries, or grain from Bulgaria, Romania and Serbia, accounted for this surplus. This, in turn, was influenced by the yields of the surrounding countries or the level of current duties and charges. The development of wheat prices thus had a direct effect on steamer traffic.

The craft along the river rested in the harbors of Barcs, Osijek, Moslavina and Zaláta in winter. With regular dredging, Barcs and Osijek were the two largest recipients of steamers, smaller ships and ship mills. Barcs played a central role in terms of steamship, partly as a steamship terminal, and partly as a destination for rafts and small boats departing from Mura and the Upper Drava. $60-70 \%$ of the river's freight traffic landed here. ${ }^{46}$

The time of transhipment from ships to rail cars and wagons and thus its costs were low. The larger cargo ships all sailed up on the Drava only to Barcs. So far, towing roads had also been built on the banks of the Drava, which the owners had to maintain. In Barcs, shipments were transferred to the railway, which at that time was the largest amount of cheap grain and timber from the south. From here these products continued its journey by rail to the rest of the empire. Animal trade was not brisk in comparison. In 1893, at four national and 104 weekly fairs, 1,200 horses, 50 oxen, 500 cows, 600 calves and 1,600 were bred, which was a good average quantity in Somogy. ${ }^{47}$

\footnotetext{
43 Erdősi, Ferenc: Adatok az egykori Dráva-hajózásról és annak Barcs fejlődésében betöltött szerepéről. Somogy megye múltjából 1971. Edited by Kanyar József. Kaposvár. 1971.

44 Barcsi Lapok, 04. 27. 1902.

45 Drávavidék, 04.25.1909.

46 Bencs, János - Dávid, Ferenc: Merre a Dráva vize öntözi Pannóniát. Drávaszabolcs nyolc évszázada. Drávaszabolcs. 2016.37.

47 A Pécsi Kereskedelmi és Iparkamara jelentése. Pécs. 1894. 56.
} 
Navigation on the Drava was important for the development of Barcs. It was important because it perfectly complemented and cooperated with the transport capacities of the other kind of transport sectors. The proximity of the port and the railway station provided an almost uniquely good basis for development. Such a high degree of concentration of transport infrastructure has attracted economic actors. ${ }^{48}$

At that time, Barcs, the agricultural settlement, was disappearing more and more behind the developing, under construction and Barcstelep with a completely different image. This part of Barcs, referred to as a "settlement" and separated from the agricultural settlement, was essentially created by the construction of the railway. As I have already mentioned, at the same time as the railway lines were being built, the Rinya creek, which until then had flowed into the Drava around today's railway station, was diverted into a new bed and the swampy meadow behind it was filled up. The Barcstelep was established in the area thus obtained during the same year.

Then Barcstelep was the heart of this Drava coastal settlement. Already in the 1880s, the bustling lives of several plants and offices in trade, industry and transport, employing many workers and employees and networking across Europe, were pulsating here. ${ }^{49}$ The people who lived here didn't really feel like they belonged to Barcs, as there were "only" farmers and craftsmen, and this is where wholesalers, businessmen, bankers and officials lived, where goods from all over the world circulated. ${ }^{50}$

The biggest importance in commercial life was the transport of grain and pigs in 1882, which was interrupted by the collapse of the Drava Bridge in Osijek in September of that year ${ }^{51}$, but more than 82,000 glaze cereals were stored in and more than 71,000 were stored out in the public warehouses which were leased by the Hungarian Discount and Exchange Bank. ${ }^{52}$ Direct rail transhipment has not always taken place due to rhapsodically changing shipping conditions depending on water level. Warehouses were needed to store crops and a variety of items in safe conditions. With long-term warehousing, the aim was to sell at the best prices and, in some cases, to influence stock prices. ${ }^{53}$ According to Imre Széchényi, Barcs had the „largest visible grain stock” after Budapest, which could hold 300,000 q (3,000 wagons) in the country. ${ }^{54}$ Each issue of local weekly newspapers provided accurate data on the turnover and stocks of public warehouses. We know from this brief news that the stocks in the warehouses fluctuated between 75,000 and $170,000 \mathrm{q}$, of which 70-80\% was wheat. The annual turnover of Barcs's warehouses grew rapidly: it was $200 \mathrm{q}$ in 1882, 848 in 1889, 1,230 in 1893, 1,380 in $1896,1,300$ in 1902 and 1,560,000 $\mathrm{q}$ in $1904 .{ }^{55}$ Rather, public warehouses are merely an aid to actual trade. 186 individuals were employed in public warehouses in Hungary and Fiume at the time of the census, however, there were no public warehouses in Croatian-Slavonia at that time. In Hungary, public warehouses have been established in Budapest, Bratislava, Barcs, Oradea, Debrecen, Nyíregyháza, Cluj-Napoca and Brasov.

\section{Conclusions}

At the beginning of the 19th century, Barcs was a small market town located in a floodplain area, but with unique features. The development of Hungarian agriculture, which was, among other things, one of the positive consequences of the Napoleonic Wars, significantly helped the

\footnotetext{
48 Harasztia, Attila: Barcs közlekedése a dualizmus korában...23.

49 T. Mérey, Klára: Barcs gazdaság- és társadalomtörténete...49.

Rózsás, Márton: Az idő sodrában...54.

Rózsás, Márton: Az idő sodrában...159 and 161.

Rózsás, Márton: Az idő sodrában...162.

Erdösi, Ferenc: Somogy megye közlekedési hálózatának kialakulása...200.

Széchényi, Imre: Somogy megye. Budapest. MTA. 1892.

Erdösi, Ferenc: Somogy megye közlekedési hálózatának kialakulása... 201.
} 
development of the settlement. Through the management and development of the Széchényi people, the farming of the majors flourished; the landlord family has always been involved in some form of major commercial, industrial, and infrastructure investment. An important aspect of the development of Barcs was the improvement of transport conditions. The railway appeared relatively early in Barcs, with its commercial and other advantages. In addition, navigation on the Drava developed continuously, to a lesser extent than the railway, and bridges over the Drava were built as a development of the Barcs ferry crossing. This further strengthened the trade relations and opportunities of the settlement. These investments had a huge impact on the life of the settlement, as even the nearest major post office before them lay farther from the border of the settlement. In addition to the rapid boom of trade, a significant industrial base was established in Barcs by the 19th century. It is no coincidence that during this period the population of Barcs grew rapidly, which was also eye-catching for his contemporaries. Barcs was rightly likened to the development of American cities. At the same time, we must also see that the development of Barcs is quite unique in the history of the Hungarian cities. The economy of Barcs peaked in the 1910s. The First World War restricted the opportunities for trade and production companies in Barcs to trade in international markets. On November 16, 1918, the village came under Serbian occupation. No one could have guessed then that this condition would last for almost three years. 